\title{
Synthesis, Characterization, Antibacterial and Anti-Inflammatory Activities of Enoxacin Metal Complexes
}

\author{
Saeed Arayne, ${ }^{1}$ Najma Sultana, ${ }^{2}$ Urooj Haroon, ${ }^{1}$ and M. Ahmed Mesaik ${ }^{3}$ \\ ${ }^{1}$ Department of Chemistry, University of Karachi, Karachi-75270, Pakistan \\ ${ }^{2}$ Department of Pharmaceutical Chemistry, Faculty of Pharmacy, University of Karachi, Karachi-75270, Pakistan \\ ${ }^{3}$ PCMD, International Centre of Chemical Sciences, University of Karachi, Karachi-75270, Pakistan
}

Correspondence should be addressed to Saeed Arayne, msarayne1@gmail.com

Received 27 January 2009; Revised 25 March 2009; Accepted 4 May 2009

Recommended by Patrick Bednarski

The present work comprises the synthesis of enoxacin (Heno) complexes with various transition metals. Two types of complexes $\left[\mathrm{M}(\mathrm{eno})_{2}\left(\mathrm{H}_{2} \mathrm{O}\right)_{2}\right] 3 \mathrm{H}_{2} \mathrm{O}\left(\mathrm{M}=\mathrm{Cu}^{\mathrm{II}}, \mathrm{Ni}^{\mathrm{II}}\right.$ or $\left.\mathrm{Mn}^{\mathrm{II}}\right)$ and $\left[\mathrm{M}(\right.$ eno $\left.)\left(\mathrm{H}_{2} \mathrm{O}\right)_{2}\right] \mathrm{Cl} \cdot 4 \mathrm{H}_{2} \mathrm{O}\left(\mathrm{M}=\mathrm{Fe}^{\mathrm{III}}\right)$ were obtained. The complexes were characterized by different physicochemical, spectroscopic, and elemental analysis. Results suggest that enoxacin interacts with the metals as a monoanionic bidentate ligand. These complexes were also tested for their antibacterial activity against eleven (11) different microorganisms, and the results were compared with the parent drug. Moreover all the metal complexes were also tested for their ability to scavenge reactive oxygen species where by $\mathrm{Mn}^{\mathrm{II}}$ and $\mathrm{Cu}^{\mathrm{II}}$ complexes exhibited potential to mediate antiinflammatory response.

Copyright () 2009 Saeed Arayne et al. This is an open access article distributed under the Creative Commons Attribution License, which permits unrestricted use, distribution, and reproduction in any medium, provided the original work is properly cited.

\section{Introduction}

Enoxacin,1-ethyl-6-fluoro-1,4-dihydro-4-oxo-7-(1-piperazinyl)-1,8-naphthyridine-3-carboxylic acid is a potent inhibitor of the bacterial enzyme DNA gyrase, exhibiting high antibacterial activity against a broad spectrum of Gram-negative and moderate activity against Gram-positive bacteria [1-3] (Figure 1).

The most important structural features necessary for meaningful antibacterial activity of enoxacin include a carboxylic acid attached to the 3-position of the quinolone nucleus and an alkyl group in the 1-position. In addition to this, fluorine attached to the 6-position and a nitrogen heterocycle attached to the 7-position is also required for their activity. This heterocycle in enoxacin is a piperazine derivative [4]. Isosteric replacements of nitrogen for carbon atom at postion $8(1,8$-napthyridines $)$ are consistent and retained the antimicrobial activity [5].

Quinolones are complexing agents for a variety of metal ions including alkaline earth and transition metal ions. Although reports indicate that the coordination of quinolones to metal ions such as $\mathrm{Cu}^{\mathrm{II}}, \mathrm{Mg}^{\mathrm{II}}$, and $\mathrm{Ca}^{\mathrm{II}}$ appear to be important for the activity of the quinolone antibiotics [6], it has a detrimental effect on their absorption [7]. Early studies by Nakano demonstrated the ability of the quinolone naldixic acid to complex a variety of metal ions [8]. The crystal structures of quinolone complexes $[9,10]$ indicate that quinolone antibiotics can participate in the formation of complexes in a number of ways. Complexes isolated from acidic media usually contain singly and/or doubly protonated quinolones that are incapable of bonding to the metal ion and in these cases only electrostatic interaction was observed between the drug and the metal ions [11, $12]$. In other cases $[13,14]$, it was found that neutral quinolones in the zwitterionic state are capable of forming simple complexes. In these complexes the quinolone acts as a bidentate ligand through the ring carbonyl group at position 4 and through one of the oxygen atoms of the carboxylato group at position 3. Quinolones can also act as bridging ligands and thus capable of forming polynuclear complexes.

Literature review reveals that there are few studies on the interaction of metal ions with enoxacin [15]. Accordingly, an attempt is made to study the interaction of enoxacin with transition metals of biological interest and to investigate the coordination chemistry of such interactions.

In the present work, we describe the synthesis and characterization of metal complexes of enoxacin. Moreover the antibacterial and anti-inflammatory activity of enoxacin 
TABle 1: Physicochemical Parameters of Enoxacin and its metal complexes.

\begin{tabular}{|c|c|c|c|c|c|}
\hline S.No & Complexes & Color & Melting point ${ }^{\circ} \mathrm{C}$ & Mole Ratio & $\%$ yield \\
\hline 1 & Enoxacin & off white & 225 & - & \\
\hline 2 & $\mathrm{Mn}^{\mathrm{II}}$ complex & off white & $265 d$ & $1: 2$ & 78 \\
\hline 3 & $\mathrm{Fe}^{\mathrm{III}}$ complex & dark brown & $275 d$ & $1: 1$ & 70 \\
\hline 4 & $\mathrm{Ni}^{\mathrm{II}}$ complex & leaf green & 246 & $1: 2$ & 76 \\
\hline 5 & $\mathrm{Cu}^{\mathrm{II}}$ complex & light blue & 255 & $1: 2$ & 72 \\
\hline
\end{tabular}

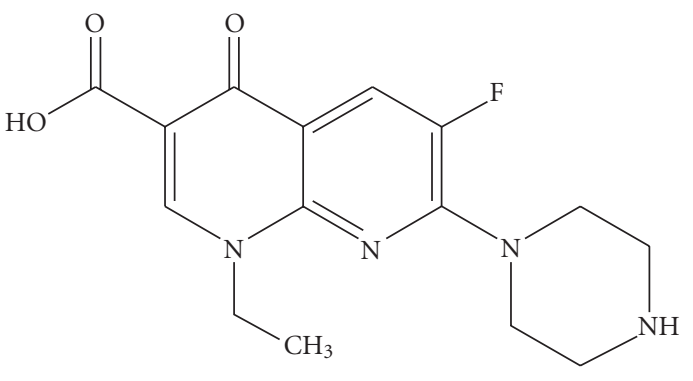

Figure 1: Enoxacin.

metal complexes is also evaluated and compared with the parent. Results suggest that metal interaction in some cases significantly altered the activity of enoxacin.

\section{Experimental}

2.1. Physical Measurements. Prior to the synthesis of the metal complexes, the metal: drug ratios were determined by conductometric titration and continuous variation method (jobs plot). Conductometry was carried on Vernier LabPro. Data acquisition and analysis was carried out by using Logger pro 3.2 software. For jobs plot the UV-Vis spectra of the drug and metal solutions (in different combination ratios) were recorded on UV-Vis spectrophotometer (Shimadzu 1601 coupled with a P IV-PC and loaded with UVPC version 3.9, software). Thin layer chromatography (TLC) was performed on HSF-254 TLC plate and the samples were visualized under UV lamp. Melting point of the metal complexes was recorded on a Gallenkamp apparatus. The characterization of enoxacin metal complexes was carried out by Fourier Transform Infrared Spectrophotometer (Shimadzu Prestige21200 VCE), coupled to a P IV-PC and loaded with IR Resolution software. The disks were placed in the holder directly in the IR laser beam. Spectra were recorded at a resolution of $2 \mathrm{~cm}^{-1}$, and 50 scans were accumulated. NMR spectra were recorded on Bruker AMX $500 \mathrm{MHz}$ spectrometer in $\mathrm{CD}_{3} \mathrm{OD}$ using TMS as an internal standard. Column chromatography was performed on Merck silica gel 60 (particle size $0.06-0.02$ ).

2.2. Synthesis of Metal Complexes. Enoxacin base was a kind gift from Zafa Pharmaceutical Laboratories Ltd., Karachi, Pakistan. The metal salts used were of analytical grade. All the glassware was washed with chromic acid followed by a thorough washing with deionized water which was freshly prepared in the laboratory.
Synthesis of metal complexes of enoxacin was carried out according to their calculated mole ratios. For this purpose enoxacin along with ferric chloride hexahydrate, manganese chloride monohydrate, nickel chloride hexahydrate, and copper chloride di hydrate were purified by recrystallization. Solvent used for the synthesis of these complexes was double distilled methanol.

The Fe ${ }^{\mathrm{III}}$ complex was synthesized by dissolving 1 mmole $(0.27 \mathrm{gm})$ of the metal salt and 1 mmole $(0.32 \mathrm{gm})$ of the drug separately in equal volume of hot methanol $(20 \mathrm{~mL})$ and then mixing the two solutions with constant stirring in a round bottomed flask. The flask was fitted to water condenser, and the solution was refluxed for about an hour. The completion of the reaction was monitored by TLC. Solvent system used was water, ethyl acetate, and acetic acid in the ratio $1: 2: 1$. In a similar way other metal complexes were synthesized taking 1 mmole $(0.144 \mathrm{gm})$ of $\mathrm{Mn}^{\mathrm{II}}$ salt, 1 mmole $(0.2374 \mathrm{gm})$ of $\mathrm{Ni}^{\mathrm{II}}$ salt, 1 mmole $(0.161 \mathrm{gm})$ of $\mathrm{Cu}^{\mathrm{II}}$ salt, and 2 mmole $(0.64 \mathrm{gm})$ of the drug. The volume of the reaction mixture was then reduced by rotary evaporation. The precipitated complexes were filtrated off, washed with water and methanol and vacuum dried. The physical characteristics of enoxacin metal complexes are given in (Table 1).

2.3. Antibacterial Studies. Disk Diffusion technique developed by Bauer et al. [16] was adopted to determine the antibacterial activity of enoxacin and all the metal complexes against 11 different clinical isolates of Gram-positive and Gram-negative organisms, that is, Klebsiella Pneumoniae, Proteus mirabilis, Staphylococcus aureus, Cornybacterium hoffmini, Shigella flexneri, Escherichia coli, Pseudomonas areuginosa, Bacillus species, Citrobacter species,Streptococcus pneumonia, and Salmonella typhi.

The antibacterial activity of the compounds (ligand, metal salt, and complexes) was determined at a concentration range of $10 \mathrm{mg} / \mathrm{disc}, 15 \mathrm{mg} / \mathrm{disc}$, and $20 \mathrm{mg} / \mathrm{disc}$. All the solutions were prepared in hot methanol. The discs were applied on the surface of the agar plate over which a culture of microorganism was already streaked. After 24 hours of incubation the clear zone of inhibition around the disc was determined; this was related to the activity of the compound against the test strain. Three replicas were made for each treatment to minimize error.

2.4. Phagocyte Chemiluminescence. Luminol-enhanced chemiluminescence assay was performed using Helfand et al. protocol [17]. Briefly whole blood diluted in modified 
TABLE 2: CHN Microanalysis of Enoxacin and its metal Complexes.

\begin{tabular}{|c|c|c|c|c|c|c|c|}
\hline S.No & Compound name & & $\mathrm{C}$ & $\mathrm{H}$ & $\mathrm{N}$ & Chloride & Metal \\
\hline \multirow{2}{*}{1} & \multirow{2}{*}{ Enoxacin } & Found & 56.42 & 5.85 & 16.99 & - & - \\
\hline & & Calculated & 56.24 & 5.35 & 17.49 & & \\
\hline \multirow{2}{*}{2} & \multirow{2}{*}[\mathrm{Mn}(\mathrm{eno})_{2}(\mathrm{H}_{2}\mathrm{O})_{2}]{$\cdot 3 \mathrm{H}_{2} \mathrm{O}$} & Found & 45.40 & 6.12 & 14.04 & - & 7.05 \\
\hline & & Calculated & 45.90 & 5.92 & 14.34 & - & 6.99 \\
\hline \multirow{2}{*}{3} & \multirow{2}{*}[\mathrm{Fe}(\mathrm{eno})(\mathrm{H}_{2}\mathrm{O})_{2}]{$\cdot \mathrm{Cl} \cdot 4 \mathrm{H}_{2} \mathrm{O}$} & Found & 33.67 & 5.27 & 10.47 & 13.2 & 10.43 \\
\hline & & Calculated & 33.73 & 5.20 & 10.58 & 13.5 & 10.24 \\
\hline \multirow{2}{*}{4} & \multirow{2}{*}[\mathrm{Ni}(\mathrm{eno})_{2}(\mathrm{H}_{2}\mathrm{O})_{2}]{$\cdot 3 \mathrm{H}_{2} \mathrm{O}$} & Found & 45.53 & 5.74 & 14.01 & - & 7.77 \\
\hline & & Calculated & 45.65 & 5.62 & 14.19 & - & 7.43 \\
\hline \multirow{2}{*}{5} & \multirow{2}{*}[\mathrm{Cu}(\text{eno})_{2}(\mathrm{H}_{2}\mathrm{O})_{2}]{$\cdot 3 \mathrm{H}_{2} \mathrm{O}$} & Found & 45.39 & 5.56 & 14.12 & - & 8.02 \\
\hline & & Calculated & 45.37 & 5.58 & 14.11 & - & 8.00 \\
\hline
\end{tabular}

Hank's solution (MHS) was incubated with different concentrations of the metal complexes $(50,25$, and $5 \mu \mathrm{g} / \mathrm{mL}$ ) for 30 minutes Zymosan (Sigma Chemical Co., USA) $100 \mu \mathrm{L}$ $(20 \mathrm{mg} / \mathrm{mL})$, followed by $100 \mu \mathrm{L}\left(7 \times 10^{5} \mathrm{M}\right)$ luminal (Sigma Chemical Co., USA) added to make a final volume of $0.25 \mathrm{~mL}$.

MHS alone was run as a control. Peak chemiluminescence of the drug and the complexes was recorded with a luminometer (Labsystem Luminoskan RS, Finland). The luminometer was set with repeated scan mode, 50 scans with 30 s intervals and one second point measuring time. The experiments were performed three times to minimize errors.

\section{Result and Discussion}

Enoxacin has a favorable solubility in acidic or basic solvents and in hot water. However the metal complexes of enoxacin were insoluble in hot water. Solubility was found in hot methanol, ethanol, and chloroform. The complexes were found to be stable at room temperature for two days [18]. The stability was checked by taking melting points of the complexes at an interval of 24 hours and 48 hours. All the samples were stored in room temperature $\left(25^{\circ} \mathrm{C}\right)$. No appreciable changes in the melting points were observed, and the estimated error was $\pm 1^{\circ} \mathrm{C}$. Melting points of the metal complexes when compared with the reference drug (Table 1) differ considerably from enoxacin. Conductometric titration (Figure 2) and jobs plot reveal that the metal: drug complexes are in the ratio $1: 1\left(\right.$ metal $\left.=\mathrm{Fe}^{\mathrm{III}}\right)$ and $1: 2\left(\right.$ metal $=\mathrm{Cu}^{\mathrm{II}}, \mathrm{Ni}^{\mathrm{II}}$ or $\left.\mathrm{Mn}^{\mathrm{II}}\right)$. Argentometric titration of Iron(III) complex using Potassium dichromate as an indicator shows one molecule of chloride ion present outside the coordination sphere of the complex. The structure of the complexes established form the elemental analyses agree well with their proposed formulae (Table 2).

In the IR spectra of enoxacin, two strong absorption peaks at 1690 and $1640 \mathrm{~cm}^{-1}$ are observed due to carboxylic and ring ketonic $(\mathrm{C}=\mathrm{O})$ groups, respectively.

On comparing the IR spectrum of enoxacin with its metal complexes it is found that the band due to carboxylic group at $\left(1690 \mathrm{~cm}^{-1}\right)$ nearly diminishes in the spectra of the complexes indicating the coordination of this moiety to the metal ions [19]. Further the absorption of the ring ketone

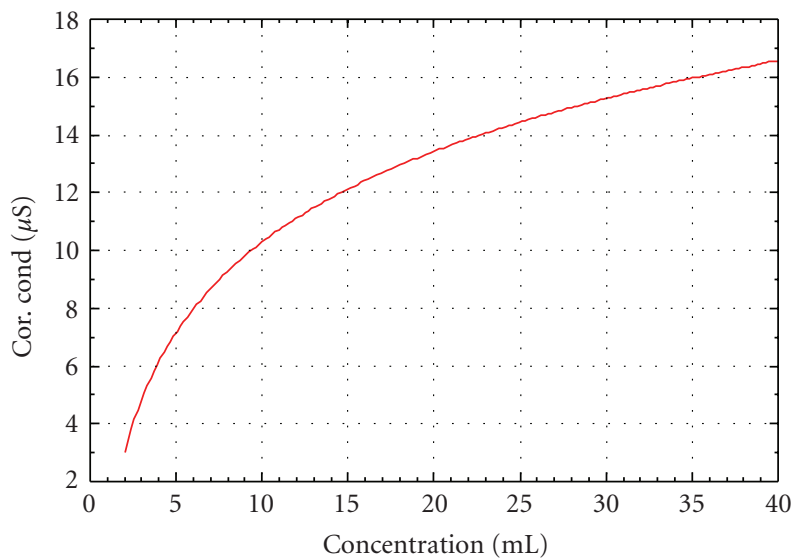

FIGURE 2: Representative conductance graph of Enoxacin and its $\mathrm{Mn}^{\mathrm{II}}$ complex.

appears at a lower frequency near $\left(1600 \mathrm{~cm}^{-1}\right)$ in the spectra of the complexes which also suggests the binding of enoxacin to the metal ions through the ring carbonyl oxygen atom [20]. A broad diffuse band of medium intensity in the region $\left(3100-3500 \mathrm{~cm}^{-1}\right)$ is assigned to the $\mathrm{OH}$ stretching vibration of the water molecules [21].

Important ${ }^{1} \mathrm{H}$ NMR signals of enoxacin are observed at chemical shifts of $1.40\left(\mathrm{t}, 3 \mathrm{H}, \mathrm{J}=7.0 \mathrm{~Hz},-\mathrm{CH}_{3}\right.$ methyl), $2.0(\mathrm{~s}, 1 \mathrm{H}$, amine), $2.62(\mathrm{~s}, 4 \mathrm{H}$, piperazine $), 3.85(\mathrm{~s}, 4 \mathrm{H}$, piperazine), 4.48 (q, $2 \mathrm{H}, \mathrm{J}=7.0 \mathrm{~Hz},-\mathrm{CH}_{2}-$ ethyl), $8.10,8.95$ (s, $2 \mathrm{H}$, naphthyridine), and $11.0(\mathrm{~s}, 1 \mathrm{H}, \mathrm{COOH})$.

On comparing main peaks of enoxacin with its complexes, it is observed that all the signals of the free ligand are present in the ${ }^{1} \mathrm{HNMR}$ spectra of the complexes. The signals for the aliphatic and piperazine protons are practically unchanged since they lie far from the binding site of the ligand [22]. However, resonance of naphthyridine proton from 8.10-8.95 appeared down field near 8.4-9.5 ppm in the spectra of all the complexes. Other studies also report that the aromatic protons exhibit a characteristic $0.3-0.5 \mathrm{ppm}$ downfield shift upon binding of the quinolones to the divalent metal ion [23]. The resonance of the carboxylic proton $(\mathrm{COOH})$ is not detected in the spectra of the complexes which further suggest the coordination of enoxacin through its carboxylate oxygen atoms [24]. The $\mathrm{OH}$ proton peak 
TABLE 3: Zone of inhibition $(\mathrm{mm})$ of enoxacin and its metal complexes.

\begin{tabular}{|c|c|c|c|c|c|c|c|c|c|c|c|c|}
\hline \multirow[t]{2}{*}{ Sample } & \multicolumn{3}{|c|}{$\begin{array}{c}\text { Corynebacterium hofmannii } \\
\text { Conc. (mg/disc) }\end{array}$} & \multicolumn{3}{|c|}{$\begin{array}{l}\text { Staphylococcus aureus } \\
\text { Conc. (mg/disc) }\end{array}$} & \multicolumn{3}{|c|}{$\begin{array}{l}\text { Bacillus subtilis } \\
\text { Conc. (mg/disc) }\end{array}$} & \multicolumn{3}{|c|}{$\begin{array}{l}\text { Shigella flexneri } \\
\text { Conc. (mg/disc) }\end{array}$} \\
\hline & 5 & 10 & 20 & 5 & 10 & 20 & 5 & 10 & 20 & 5 & 10 & 20 \\
\hline Enoxacin & 8 & 14 & 16 & 8 & 10 & 14 & 8 & 10 & 12 & 8 & 11 & 13 \\
\hline Enox $+\mathrm{Mn}$ & 10 & 16 & 20 & 15 & 20 & 21 & 12 & 15 & 16 & 8 & 9 & 13 \\
\hline Enox $+\mathrm{Fe}$ & 8 & 10 & 10 & 10 & 10 & 10 & 7 & 9 & 11 & 7 & 8 & 10 \\
\hline Enox $+\mathrm{Ni}$ & 14 & 18 & 24 & 7 & 10 & 10 & 10 & 12 & 16 & 10 & 11 & 15 \\
\hline Enox + Cu & 11 & 13 & 17 & 14 & 15 & 20 & 10 & 11 & 11 & 8 & 11 & 12 \\
\hline
\end{tabular}

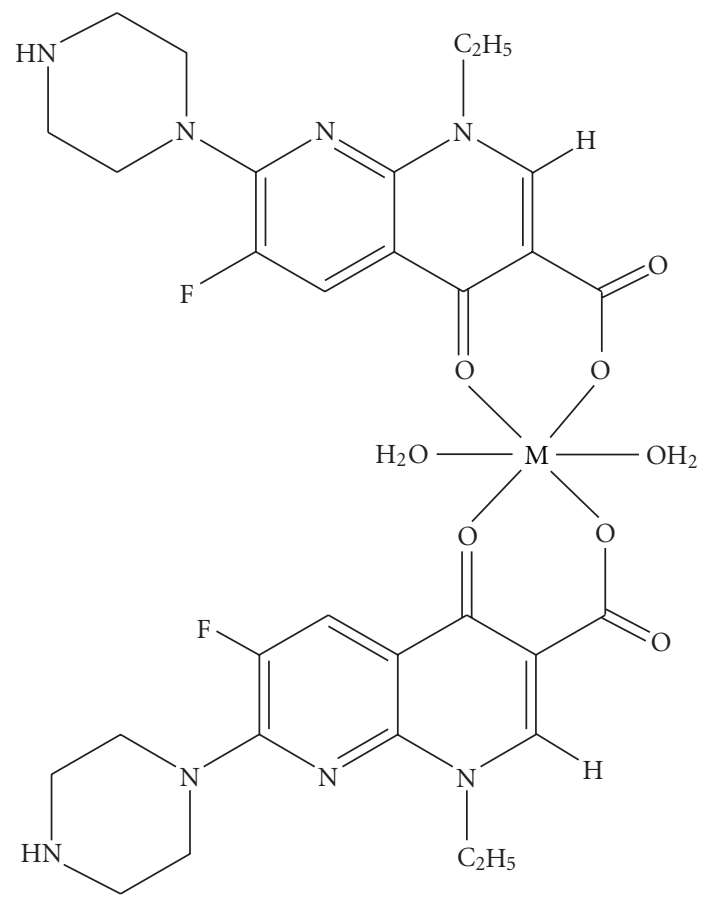

Figure 3: Tentative structure of $\mathrm{Cu}^{\mathrm{II}}, \mathrm{Mn}^{\mathrm{II}}$, and $\mathrm{Ni}^{\mathrm{II}}$ complexes of enoxacin.

appears near $3.5 \mathrm{ppm}$, adjacent to the piperazine protons, due to the presence of lattice water.

Our studies suggest that enoxacin acts as a monoanionic bidentate ligand and interacts with the metal centre through the 3-carboxylate and 4-oxygen atom. From the results obtained, it is proposed that the Manganese(II), Nickel(II), and Copper(II) complexes are probably six coordinate with two molecules of enoxacin chelating the central metal atom from four sides and two molecules of water at the vertices of an octahedron (Figure 3). Alternatively, the enoxacin complex of Iron(III) is four coordinate with probably one molecule of the drug and two molecules of water along the edge of a tetrahedron (Figure 4). Despite the crystalline nature of the products, we did not manage to obtain crystals suitable for determination of structures with X-ray crystallography $[21,22]$.

3.1. Antibacterial Studies. The zone of inhibition around the antibiotic discs is related to the susceptibility of the

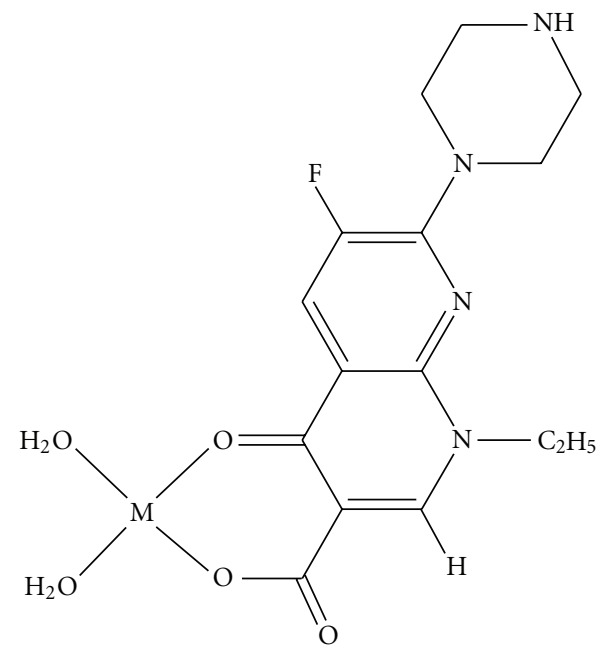

FIgUre 4: Tentative structure of Fe $\mathrm{III}^{\mathrm{III}}$ complex of enoxacin.

organisms toward enoxacin and its metal complexes (Tables 3,4 , and 5). Standard deviation values amongst replicate responses were $<0.6$ indicating precision of the disc diffusion method.

It was observed that Nickel(II) complex exhibited increased antimicrobial effect than enoxacin against all the test strains except Staphylococcus aureus. Manganese(II) complex showed improved activity against Staphylococcus aureus and Bacillus subtilis while Copper(II) complex proved to be more active against Citrobacter and Staphylococcus aureus. Nearly all metal complexes showed increased activity as compared to enoxacin against Corynebacterium hofmannii except Iron(III) complex, which was found to possess reduced activity against all the test strains as compared to enoxacin itself. Activity of Manganese(II) and Copper(II) complexes was depressed against Escherichia coli, Pseudomonas aeruginosa and Salmonella typhi while against Streptococcus pneumoniae, Klebsiella pneumoniae, Shigella flexneri, and Proteus mirabilis no appreciable change in activity was observed probably due to the intracellular biological conversion of the complexes [25].

The increased activity of metal chelates can be explained on the basis of the overtone concept and chelation theory. According to the overtone concept of cell permeability, the lipid membrane that surrounds the cell favors the passage of only lipid-soluble materials in which liposolubility is an 
TABLE 4: Zone of inhibition ( $\mathrm{mm}$ ) of enoxacin and its metal complexes.

\begin{tabular}{|c|c|c|c|c|c|c|c|c|c|c|c|c|}
\hline \multirow[t]{2}{*}{ Sample } & \multicolumn{3}{|c|}{$\begin{array}{l}\text { Pseudomonas areuginosa } \\
\text { Conc. }(\mathrm{mg} / \mathrm{disc})\end{array}$} & \multicolumn{3}{|c|}{$\begin{array}{l}\text { Salmonella typhi } \\
\text { Conc. (mg/disc) }\end{array}$} & \multicolumn{3}{|c|}{$\begin{array}{l}\text { Streptococcus pneumonia } \\
\text { Conc. (mg/disc) }\end{array}$} & \multicolumn{3}{|c|}{$\begin{array}{c}\text { Citrobacter } \\
\text { Conc. (mg/disc) }\end{array}$} \\
\hline & 5 & 10 & 20 & 5 & 10 & 20 & 5 & 10 & 20 & 5 & 10 & 20 \\
\hline Enoxacin & 12 & 16 & 18 & 12 & 17 & 21 & 9 & 12 & 14 & 10 & 12 & 14 \\
\hline Enox $+\mathrm{Mn}$ & 9 & 12 & 15 & 10 & 15 & 18 & 9 & 12 & 14 & 10 & 10 & 11 \\
\hline Enox $+\mathrm{Fe}$ & 8 & 8 & 10 & 9 & 10 & 12 & 8 & 10 & 12 & 10 & 12 & 12 \\
\hline Enox $+\mathrm{Ni}$ & 13 & 18 & 20 & 11 & 17 & 22 & 10 & 12 & 22 & 14 & 15 & 18 \\
\hline Enox $+\mathrm{Cu}$ & 10 & 11 & 12 & 8 & 12 & 14 & 11 & 13 & 13 & 14 & 16 & 18 \\
\hline
\end{tabular}

TABle 5: Zone of inhibition ( $\mathrm{mm}$ ) of enoxacin and its metal complexes.

\begin{tabular}{|c|c|c|c|c|c|c|c|c|c|}
\hline \multirow[t]{2}{*}{ Sample } & \multicolumn{3}{|c|}{$\begin{array}{l}\text { Escherichia coli } \\
\text { Conc. (mg/disc) }\end{array}$} & \multicolumn{3}{|c|}{$\begin{array}{l}\text { Klebsiella pneumonia } \\
\text { Conc. (mg/disc) }\end{array}$} & \multicolumn{3}{|c|}{$\begin{array}{l}\text { Proteus mirabilis } \\
\text { Conc. }(\mathrm{mg} / \mathrm{disc})\end{array}$} \\
\hline & 5 & 10 & 20 & 5 & 10 & 20 & 5 & 10 & 20 \\
\hline Enoxacin & 12 & 15 & 19 & 9 & 12 & 13 & 10 & 13 & 14 \\
\hline Enox $+\mathrm{Mn}$ & 12 & 13 & 14 & 11 & 11 & 12 & 10 & 11 & 13 \\
\hline Enox $+\mathrm{Fe}$ & 10 & 11 & 12 & 9 & 11 & 11 & 11 & 13 & 12 \\
\hline Enox $+\mathrm{Ni}$ & 14 & 16 & 25 & 11 & 14 & 18 & 10 & 12 & 20 \\
\hline $\mathrm{Enox}+\mathrm{Cu}$ & 10 & 12 & 12 & 10 & 11 & 13 & 11 & 13 & 13 \\
\hline
\end{tabular}

important factor that controls the antimicrobial activity. On chelation the polarity of the metal ion will be reduced to a greater extent due to overlap of ligand orbital and partial sharing of the positive charge of the metal ion with donor groups. Further it increases the delocalization of $\pi$-electrons over the whole chelate ring and enhances the lipophilicity of complexes [26]. It is likely that the increased liposolubility of the ligand upon metal complexation may contribute to its facile transport into the bacterial cell which blocks the metal binding sites in enzymes of microorganisms. These complexes also disturb the respiration process of the cell and thus block the synthesis of proteins, which restricts further growth of the organism [24].

The antimicrobial activity of the metal salts was also investigated. It was found that the metal salts did not exhibit antimicrobial activity at the concentration range used to assay the activity of the complexes in our work [22, 27].

3.2. Effect on Phagocytes Oxidative Burst. In order to test the immunomodulatory effect of the drug and its metal complexes, we investigated their effect on the oxidative burst activity of whole blood phagocytes. Phagocytic cells on activation induce release of reactive oxygen free radicals (oxidative burst) which is then quantified by a luminolenhanced chemiluminescence assay. Results indicate that the zymosan- induced oxidative burst in whole blood phagocytes was inhibited (up to $50 \%$ ) by Manganese(II) complex at a concentration of $15.3 \pm 0.7(\mu \mathrm{g} / \mathrm{mL})$ while Copper(II) complex produced $50 \%$ inhibition at a concentration of $18.7 \pm 2.1(\mu \mathrm{g} / \mathrm{mL})$. Both enoxacin and its Iron(III) and Nickel(II) complex produced $50 \%$ inhibition at a concentration above $50(\mu \mathrm{g} / \mathrm{mL})$. Hence it is inferred that only Manganese(II) and Copper(II) complexes showed moderate inhibitory activity with $\mathrm{IC}_{50}$ ranging between $15-19 \mu \mathrm{g} / \mathrm{ml}$ while the drug and other complexes have negligible effect on the oxidative burst response. The molecular mechanism causing the immunomodulatory effects of fluoroquinolones and their complexes are still under investigation [28].

\section{Conclusion}

Many drugs possess modified toxicological and pharmacological properties when in the form of metal complexes [29]. Present work deals with the synthesis of enoxacin metal complexes and the evaluation of the synergistic or antagonistic behavior of these complexes in comparison to the parent, through the difference in their biological activities. The complexes showed a diverse antimicrobial activity as compared to enoxacin which is attributed to the formation of metal drug chelates. Although complexation with metals is known to boost biological activities of the quinolones; yet in the form of Iron(III) complex, activity of enoxacin was immensely decreased which may produce a detrimental effect in its therapeutic efficacy. Nevertheless, complexation with Nickel(II) resulted in improved antimicrobial profile of the drug while Manganese(II) and Copper(II) metal complexes modulated oxidative burst response of phagocytes and unlike enoxacin could have potential to be antiinflammatory, as they suppressed the production of reactive oxygen species.

\section{References}

[1] M. J. Wood, "Tissue penetration and clinical efficacy of enoxacin in respiratory tract infections," Clinical Pharmacokinetics, vol. 16, pp. 38-45, 1989.

[2] J. H. Paton and D. S. Reeves, "Fluoroquinolone antibiotics. Microbiology, pharmacokinetics and clinical use," Drugs, vol. 36, no. 2, pp. 193-228, 1988. 
[3] N. X. Chin and H. C. Neu, "In vitro activity of enoxacin, a quinolone carboxylic acid, compared with those of norfloxacin, new $\beta$-lactams, aminoglycosides, and trimethoprim," Antimicrobial Agents and Chemotherapy, vol. 24, no. 5, pp. 754-763, 1983.

[4] J. Matsumoto, T. Miyamoto, A. Minamida, Y. Nichimura, H. Egawa, and H. Nishimura, "1,4-Dihydro-4-oxopyridinecarboxylic acids as antibacterial agents. 2. Synthesis and structure-activity relationships of 1,6,7-trisubstituted 1,4dihydro-4-oxo-1,8-naphthyridine-3-carboxylic acids, including enoxacin, a new antibacterial agent," Journal of Medicinal Chemistry, vol. 27, pp. 293-301, 1984.

[5] L. A. Jaber, E. M. Bailey, and M. J. Rybak, "Enoxacin: a new fluoroquinolone," Clinical Pharmacy, vol. 8, no. 2, pp. 97-107, 1989.

[6] E. K. Efthimiadou, G. Psomas, Y. Sanakis, N. Katsaros, and A. Karaliota, "Metal complexes with the quinolone antibacterial agent $N$-propyl-norfloxacin: synthesis, structure and bioactivity," Journal of Inorganic Biochemistry, vol. 101, no. 3, pp. 525-535, 2007.

[7] T. Motoya, M. Miyashita, A. Kawachi, and K. Yamada, "Effects of ascorbic acid on interactions between ciprofloxacin and ferrous sulphate, sodium ferrous citrate or ferric pyrophosphate, in mice," Journal of Pharmacy and Pharmacology, vol. 52, no. 4, pp. 397-401, 2000.

[8] M. Nakano, M. Yamamoto, and T. Arita, "Interactions of aluminum, magnesium, and calcium ions with nalidixic acid," Chemical and Pharmaceutical Bulletin, vol. 26, no. 5, pp. 15051510, 1978.

[9] M. Ruiz, R. Ortiz, L. Perello, S. Granda, and M. R. Diaz, "Synthesis and characterization of Cd(II) complexes of cinoxacin. Crystal structure of a dicadmium complex containing two monoatomic-bridging carboxylate oxygen atoms," Inorganica Chimica Acta, vol. 217, no. 1-2, pp. 149-154, 1994.

[10] M. Ruiz, L. Perello, J. Cario, et al., "Cinoxacin complexes with divalent metal ions. Spectroscopic characterization. Crystal structure of a new dinuclear Cd(II) complex having two chelate-bridging carboxylate groups. Antibacterial studies," Journal of Inorganic Biochemistry, vol. 69, no. 4, pp. 231-239, 1998.

[11] I. Turel, I. Leban, G. Klintschar, N. Bukovec, and S. Zalar, "Synthesis, crystal structure, and characterization of two metal-quinolone compounds," Journal of Inorganic Biochemistry, vol. 66, no. 2, pp. 77-82, 1997.

[12] I. Turel, I. Leban, and N. Bukovec, "Crystal structure and characterization of the bismuth(III) compound with quinolone family member (ciprofloxacin). Antibacterial study," Journal of Inorganic Biochemistry, vol. 66, no. 4, pp. 241-245, 1997.

[13] B. Macias, M. V. Villa, I. Rubio, A. Castineiras, and J. Borras, "Complexes of $\mathrm{Ni}(\mathrm{II})$ and $\mathrm{Cu}(\mathrm{II})$ with ofloxacin: crystal structure of a new $\mathrm{Cu}(\mathrm{II})$ ofloxacin complex," Journal of Inorganic Biochemistry, vol. 84, no. 3-4, pp. 163-170, 2001.

[14] Z.-F. Chcn, R.-G. Xiong, J.-L. Zuo, Z. Guo, X.-Z. You, and H.K. Funb, "X-Ray crystal structures of $\mathrm{Mg}^{2+}$ and $\mathrm{Ca}^{2+}$ dimers of the antibacterial drug norfloxacin," Journal of the Chemical Society, Dalton Transactions, no. 22, pp. 4013-4014, 2000.

[15] N. Jiménez-Garrido, L. Perelló, R. Ortiz, et al., "Antibacterial studies, DNA oxidative cleavage, and crystal structures of $\mathrm{Cu}$ (II) and $\mathrm{Co}$ (II) complexes with two quinolone family members, ciprofloxacin and enoxacin," Journal of Inorganic Biochemistry, vol. 99, no. 3, pp. 677-689, 2005.

[16] A. W. Bauer, W. M. Kirby, J. C. Sherris, and M. Turck, "Antibiotic susceptibility testing by a standardized single disk method," American Journal of Clinical Pathology, vol. 45, no. 4, pp. 493-496, 1966.

[17] S. L. Helfand, J. Werkmeister, and J. C. Roder, "Chemiluminescence response of human natural killer cells-I: the relationship between target cell binding, chemiluminescence, and cytolysis," Journal of Experimental Medicine, vol. 156, no. 2, pp. 492-505, 1982.

[18] M. E. El-Kommos, G. A. Saleh, S. M. El-Gizawi, and M. A. Abou-Elwafa, "Spectrofluorometric determination of certain quinolone antibacterials using metal chelation," Talanta, vol. 60, no. 5, pp. 1033-1050, 2003.

[19] W. Guangguo, W. Guoping, F. Xuchun, and Z. Longguan, "Synthesis, crystal structure, stacking effect and antibacterial, studies of a novel quaternary copper (II) complex with quinolone," Molecules, vol. 8, pp. 287-296, 2003.

[20] S. Lecomte, M. H. Baron, M. T. Chenon, C. Coupry, and N. J. Moreau, "Effect of magnesium complexation by fluoroquinolones on their antibacterial properties," Antimicrobial Agents and Chemotherapy, vol. 38, no. 12, pp. 2810-2816, 1994.

[21] J. R. Anacona and C. Toledo, "Synthesis and antibacterial activity of metal complexes of ciprofloxacin," Transition Metal Chemistry, vol. 26, no. 1-2, pp. 228-231, 2001.

[22] E. K. Efthimiadou, Y. Sanakis, N. Katsaros, A. Karaliota, and G. Psomas, "Transition metal complexes with the quinolone antibacterial agent pipemidic acid: synthesis, characterization and biological activity," Polyhedron, vol. 26, no. 5, pp. 11481158, 2007.

[23] T. Skauge, I. Turel, and E. Sletten, "Interaction between ciprofloxacin and DNA mediated by $\mathrm{Mg}^{2+}$-ions," Inorganica Chimica Acta, vol. 339, pp. 239-247, 2002.

[24] M. Imran, J. Iqbal, S. Iqbal, and N. Ijaz, "In vitro antibacterial studies of ciprofloxacin-imines and their complexes with $\mathrm{Cu}(\mathrm{II}), \mathrm{Ni}(\mathrm{II}), \mathrm{Co}(\mathrm{II})$, and $\mathrm{Zn}(\mathrm{II})$," Turkish Journal of Biology, vol. 31, no. 2, pp. 67-72, 2007.

[25] P. Drevenšek, J. Košmrlj, G. Giester, et al., "X-Ray crystallographic, NMR and antimicrobial activity studies of magnesium complexes of fluoroquinolones-racemic ofloxacin and its S-form, levofloxacin," Journal of Inorganic Biochemistry, vol. 100, no. 11, pp. 1755-1763, 2006.

[26] M. Tumer, H. Koksal, M. K. Sener, and S. Serin, "Antimicrobial activity studies of the binuclear metal complexes derived from tridentate Schiff base ligands," Transition Metal Chemistry, vol. 24, no. 4, pp. 414-420, 1999.

[27] D. Petra, Z. Tatjana, P. Boris, et al., "Mixed-valence $\mathrm{Cu}(\mathrm{II}) / \mathrm{Cu}(\mathrm{I})$ complex of quinolone ciprofloxacin isolated by a hydrothermal reaction in the presence of l-histidine: comparison of biological activities of various copper-ciprofloxacin compounds," Journal of Inorganic Biochemistry, vol. 99, no. 2, pp. 432-442, 2005.

[28] S. C. Tauber and R. Nau, "Immunomodulatory properties of antibiotics," Current Molecular Pharmacology, vol. 1, pp. 6879, 2008.

[29] N. Sultana and M. S. Arayne, "In vitro activity of cefadroxil, cephalexin, cefatrizine and cefpirome in presence of essential and trace elements," Pakistan Journal of Pharmaceutical Sciences, vol. 20, no. 4, pp. 305-310, 2007. 


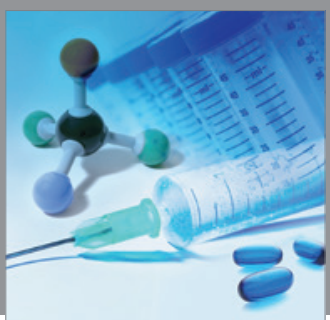

International Journal of

Medicinal Chemistry

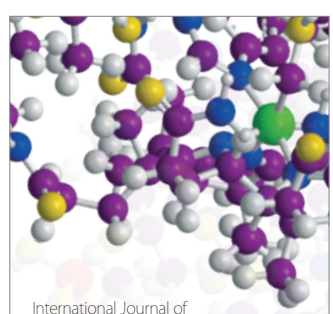

Carbohydrate Chemistry

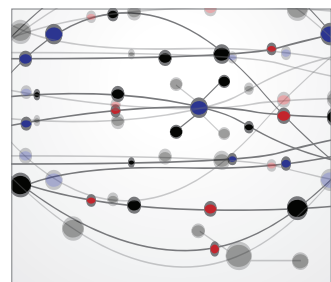

The Scientific World Journal
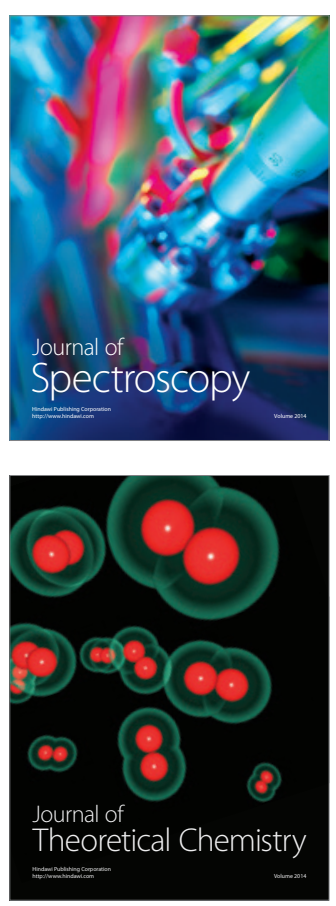
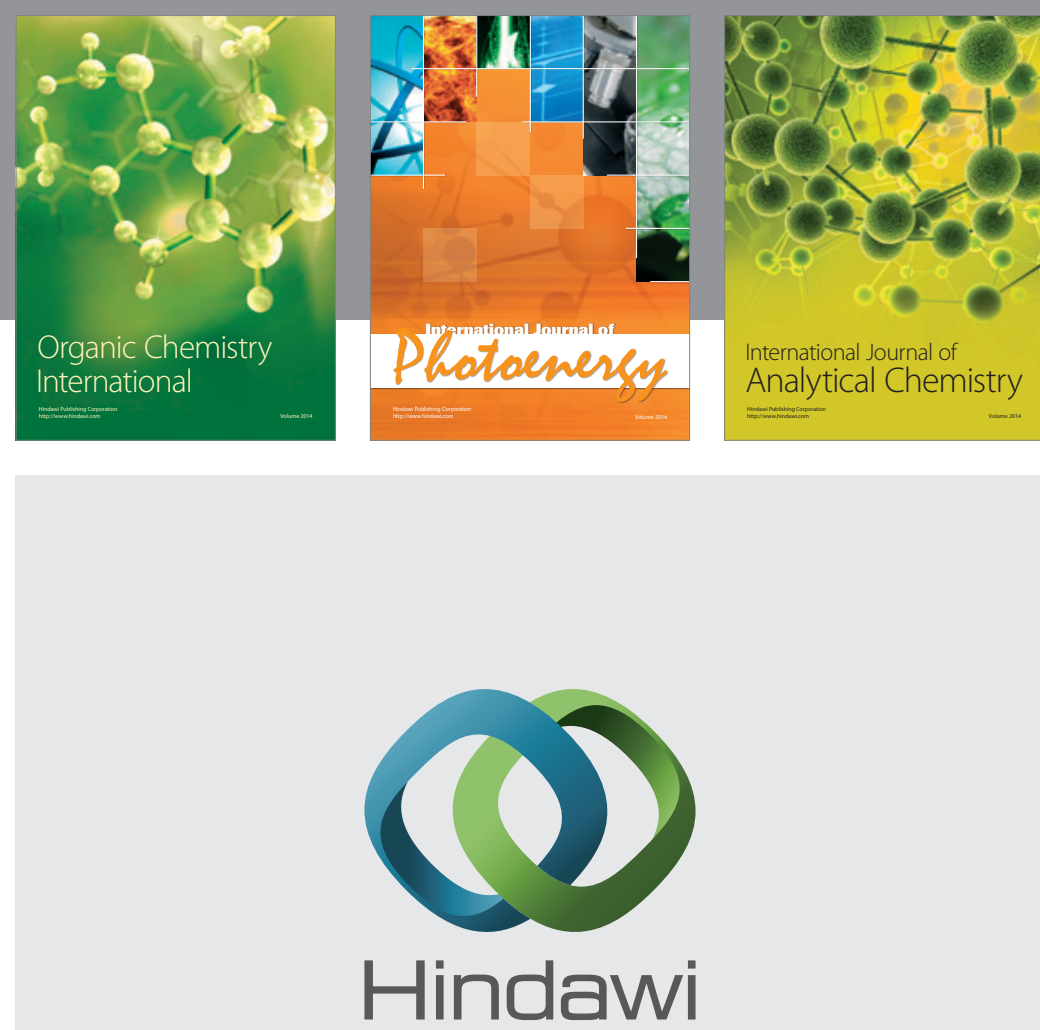

Submit your manuscripts at

http://www.hindawi.com
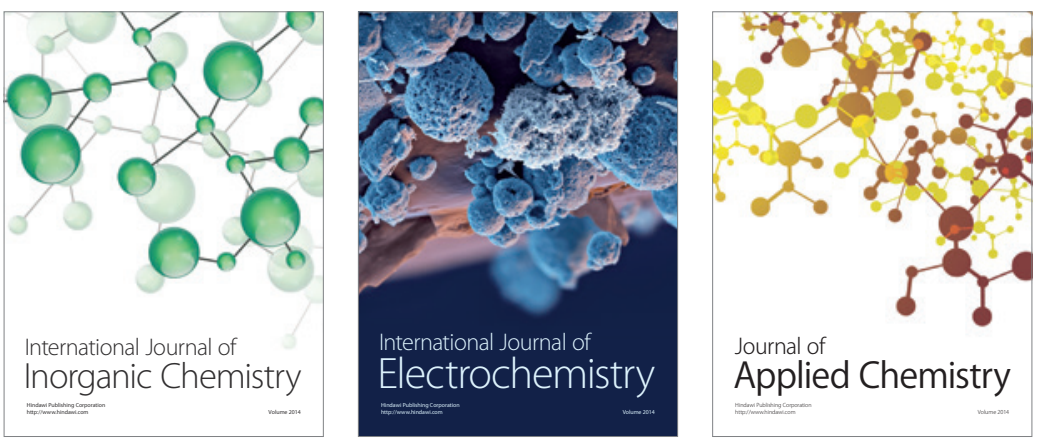

Journal of

Applied Chemistry
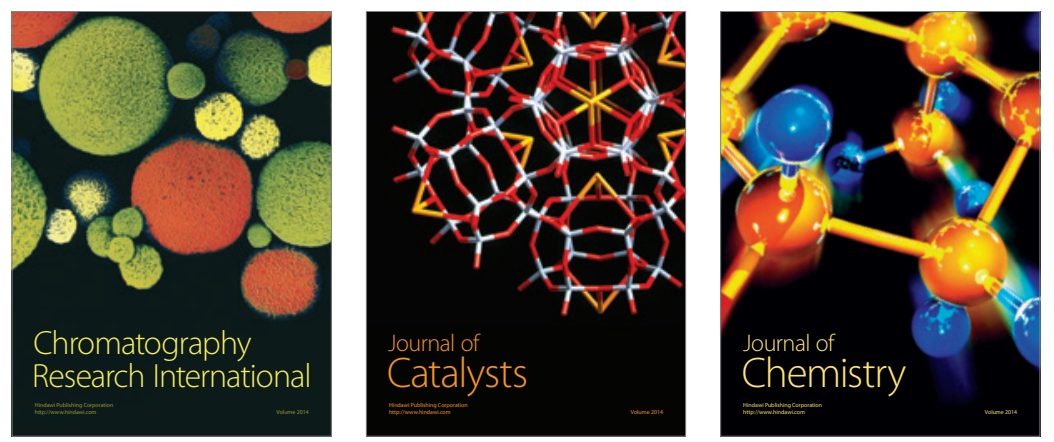
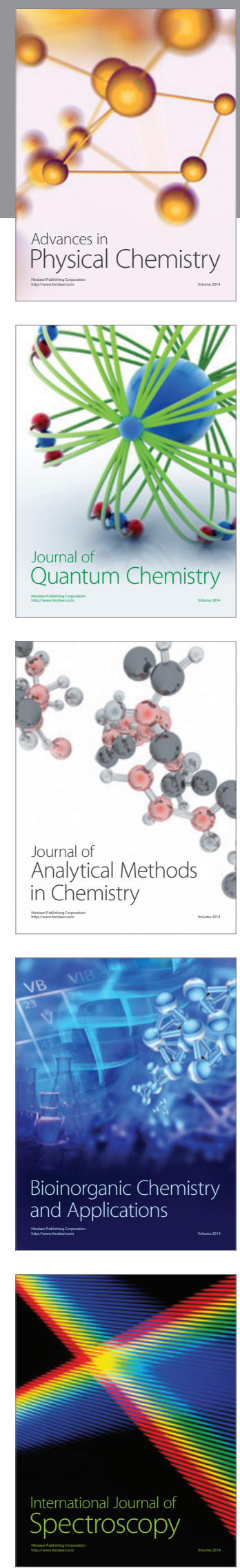